\title{
Strategy of Character Education for children within the family
}

\author{
Irnawita \\ Non Formal Educational \\ Faculty of Education Universitas Negeri Padang \\ irmawitapls@gmail.com
}

\begin{abstract}
The child is a small person who is not yet empowered, but has the potential to be empowered through education by parents, community and teachers (pamong). Education provided by parents in the family can be done in the form of service, attention, affection and be role models for children. Besides, the nature of the mine becomes a teacher by the child to be able to shape his character and character. Parenting strategies in addressing children in their daily life in the form of guidance and direction and provide good examples should be parents in family education. Education in the family is the main education and first obtained by the child, because the first time children know the various values and norms in life. The main education is education in the family oriented to moral education and the rules of life instilled by the family through care and compassion. In the family the child is taught to communicate and perform actions that do not violate the norms of life such as hospitality, honesty, trustand respect for others. Parents are very instrumental in bringing the child towards independence and maturity. There are several stages that are done in the family in the education of children according to age and developmental level. Basis in family education is moral education and character then explained also about moral education of children in the family. Morals have spontaneous deeds, free of engineering and certain interests. Some moral requirements can be fulfilled as follows: (a) The act was done repeatedly. (b) If an act is done only once, then it can not be called morals. (c). The mutation arose easily without being thought through or examined first, so it really is a habit. Some morals demanded in a child, namely morals to God, parents, relatives, friends, neighbors, nature and so on.
\end{abstract}

Keywords-strategy; education; akhlak; children; family.

\section{INTRODUCTION}

Educating children is a noble job, is the most precious gift of Almighty (Allah) to be grateful, because not every family have child that given by God. Grace given that should be maintained, nurtured and educated to be a knowledgeable and devoted beings that they survived in the world and have a provision for the afterlife[1].The education can be implemented through three channels: education in the family (informal), education in school (formal) and education in community (nonformal). These three pathways are implemented by the well child of his life known as (life long education)[2].

Education in the family is the main education and first obtained by the child, because the first time children know the various values and norms in life. The main education is education in the family oriented to moral education and the rules of life instilled by the family through care and compassion. In the family the child is taught to communicate and perform actions that do not violate the norms of life such as hospitality, honesty, trust and respect for others. Parents are very instrumental in bringing the child towards independence and maturity. There are several stages that are done in the family in the education of children according to age and developmental level. The following describes the child's education strategy in the family: (a) during pregnancy; (b) under-five; (c) of age of Kindergarten; (d) Primary school age; (e) Junior High School age and (f) High School age. The foundation in family education is moral education and character then explained also about moral education of children in the family.

\section{DISCUSSION}

\section{Education in Pregnancy}

In educating children who are still in the womb, there are some problems that need attention from parents or prospective parents[3]. The problems include:

Food Issues. In a pregnant woman, the food processed in her stomach is partly intended for the growth of the child she is carrying, both physical growth and the growth of her soul can be believed from what she will bring good or bad impact on the child being conceived. There are some things that need to be paid attention by parents or prospective parents about food, among others, as follows: quality of food and Sources and ways of obtaining food. Simple food can be said to be food that meets health standards or measures.Sources and ways of obtaining food :The source and way of getting noteworthy food is the source and manner of unlawful, both religious laws and other laws that govern human life in this world.

Parental Behavior Problems. Behavior in Intercourse : Educating the child in the womb should be the parent intercourse done by the prospective parent pay attention to the physical condition, condition and atmosphere, and read the prayer before intercourse done[4].Daily Behavior : Parents' daily behavior should include: (1) An awareness of rights and responsibilities; (2) Good social awareness; (3) Having a sense of togetherness; (4) Has no intention to misbehave; (5) Be honest and act; (6) Having openness to receive and correct; (7) Creating a happy home; (8) Candidates should be able to capture the wife's gesture of 
being or being pregnant; (9) Do not forget to pray and pray to God; and (9) Do not disagree pregnancy, despite the rapid arrival of what is expected

\section{Educating for Children under five}

Efforts to educate children under five (under the age of five years) among others can be done as follows[5]: (1) Not being excessive; (2) In the case of silencing a crying child, the avoidance of frightening means should be avoided; (3) In breastfeeding children (especially for mothers), should be cultivated not past the age of two years; (4) When our child has started to learn to speak, teach short words that are the introduction to the people closest; (5) When feeding the children get used to parents read prayers first; (6) When the child has started to learn to walk and one day mingkin fall, then when he fell indirectly helped; (7) In terms of giving toy goods, we will choose which can stimulate the creative power of children; (8) Our son asks to be able to take and put his own toys in place; (9) Educate children to be generous and caring for others; (10) In child's sleep should be with fairy tales of religious stories and songs; (11) Prepare the stationery when the child is starting to want to doodle; (12) We teach children to start a job by reading prayers; (13) Provide pictures that can draw the attention of the child so he will ask; (14) Parents should provide special times for chatting, joking with children freely; (15) Do not scold let alone form or say harshly if a child destroys something in the house; (16) It's good day of birth child is commemorated; (17) Parents should avoid having bad behaviors in front of children; (18) Avoid wearing clothes that are opposite to the child's gender; (19) children with a variety of activities appropriate to the age, nature, gender and level of child development; (20) Clever parents observe the growth and development of children; and (21) In many cases, parents should be able to play the role of teachers who should be imitated by their children and

\section{Educate the Kindergarten Child}

After the child through the age of five, now our children begin to enter kindergarten (5-6 years) and enter school. Education not only from parents but also comes from his kindergarten teacher, this situation will bring changes to the child. Changes that are increasingly ushering our child to be more widespread in moving, recognize the environment outside himself, outside his home. Educational behavior that must be done by parents to children of kindergarten[6]: (1) Parents begin to explain to the child that he is now a student; (2) When children should go to school, should not always be delivered, except the first days only; (3).If the word pick up the child pick up by private vehicle try to include our child's school friend; (4).Parents should be able to follow the development of children and their learning outcomes, in terms of what children have advantages and disadvantages (5).Parents should be able to give praise and appreciation for learning achievement (6).Giving something as a gift to our child's teacher, whose surrender through the child, is also a good act, as long as it is in a reasonable form; (7).In case the child gets the task of the teacher to do at home, the parents do not take over the task; (8).Parents ask about what teachers have been taught and asked to repeat, according to what the child has done; (9).Parents ask their children to learn how to pack their school supplies, store in a designated place, wear their own clothes; (10).Parents do not take action against what is done by our child's teacher; (11).In many ways, parents should always appear as teachers for their children; (12).For children who are not enrolled in kindergarten then parents should be able to give instruction to children that are adjusted to the pattern of education in kindergarten schools; (13).As we carry out the teaching and educating tasks we are used to separating as parental status and as educators; (14).In order to support the creation of a similar learning process in school, parents should really be able to form formal learning situations; (15).In order for children to feel not alone, then it is worth looking for a college friend who is the same age who is not in kindergarten; (16).If parents can not do, it would not hurt to ask other people who have the ability to educate or teach kindergarten children; and (17).As a parent we should not neglect the education of our children

\section{Educate Primary School Children}

Some educational actions that we should do are[7]: (1) Make a habit of getting used to doing good things; (2) Against duties or obligations at home, parents should start giving ration naturally; (3) Give understanding to the child if they want to enter the parent's room; (4).Parents do not show romantic scenes in front of children; (5).Teaches about religious beliefs to children from an early age; (6).Do not teach children to lie; (7).The habit of reading scriptures, worshiping, eating together with children is a very good thing; (8).Watching TV, should choose the appropriate type of film and have the value of education for children; (9).Invite children to bertsilaturahmi or visiting family homes, friends (10).Invite children to recreate; (11).Asking a child about something such as school, lessons received at the school; (12).Invite children to visit people who are sick which is a positive behavior; (13). Growing a sense of love to the homeland, nation, and country in children; and (14).To in still a sense of responsibility of living in a society and environment.

Educational measures have to do with financial or existing financial conditions. We do not have to push ourselves beyond our ability. Provided that the need to be maintained is sutu conditions where the simplest circumstances too, the obligation to educate that is borne above our shoulders as parents can still be implemented. That the education we give our children is an invaluable investment and very valuable to the lives, lives and livelihoods of our children in the future, at a time when our children have been like us, as adults, as parents.

\section{Educating Children In Junior High School}

Now, our 12 to 15 -year-old child is in high school. He has now grown as a bigger individual and has grown up, though in the category of a small teenager[7]. As a parent who previously may still be more always set up, should have begun to reduce the portion of regulating children, replaced with ways that more respect for human dignity, among others as follows: (1) Not treating children as just objects in the 
family; (2).The child as an individual has the right to life, the right to freedom, and the right to have something acceptable to him in a natural way; (3).Do not scold and say harshly to the child should openly view the place, situation and conditions; (4).Not treating children authoritatively and absolute; (5).When children make mistakes parents should give the opportunity to realize, regret, apologize, and improve themselves; (6).If the child has a choice about a choice about something that is considered good for him, then we must give him the opportunity to prove the right or wrong choice he has done; (7).Educate Children in Responsibility with Obligations

Liability is something that must be given to another party, in respect of the obligation: (1) Parents begin by giving an explanation of the meaning of obligations and what they are obligated to do; (2). Should be given responsibility for some work that corresponds to age, ability, stage of development, and gender; (3).With regard to the obligation to learn; (4).With respect to duty to religion; (5) With regard to obligations to nusa, nation and state; (6) With respect to the obligation to others; and (7) With regard to the obligation to society to society and environment.

\section{Educate Children with Rights}

Rights are something that must be received by someone from other parties[8]. The rights of the child that must be given by parents as follows: (1) Give the widest opportunity to the child so that they can enjoy their rights; (2).Do not restrict the child in mingling, not set how to get along with his friends; (3).Not entering the child's room, especially girls; and (4).Do not open and read the child's personal letter or personal note of the child without the child's knowledge.

The child has the right to own something, as we mankind, in this case we as parents should act as follows: (1) Giving attention to the child the process of possession of something that should not be against the law such as religious law, state law, moral law and others; (2).Giving an explanation to the child that there are goods or objects that can not or should not be according to law such as different haram according to religion, legal according to the law of the country; and (3).Goods or objects owned by others, state property, and others.

\section{Educate Senior High School Children}

Ways to educate high school/teenager, we can recognize individuals first when the child is now called puberty[7], which is as follows: (1) Puberty is called the socialization process in search of identity; (2).It is not easy for pubescent teenagers to fight parents if they are "understood" rather than suppressed; (3).In the eyes of teenagers/puber parents show attitude and behavior that can damage (destructive); (4).Parents worry about adolescent pity to adjust to the habits, ways of speaking, and dressing set by the group; (5).Adolescents / pubes often exhibit more mature attitudes about traits andthe environment; (6) The adolescent/ publisher looks for strengths, weaknesses, and endurance tests; (7).Teens / pubers have a lumpy feeling between the advantages and disadvantages; (8).Teenagers / pubes are sensitive to success and failure; (9).Teenagers / pubers feel anxious about the nature of the changes that are so rapidly happening around him; (10).Teens / pubers are always anxious about the unsatisfied desire to eat and attitudes toward the sex that can not dikusainya well.

a. Teens / pubes seek freedom or independence, but also expect a sense of well-being.

b. The adolescent / publisher wants to assign a waktun distribution according to his own tastes.

c. Teens / pubers want to see the symbols of maturity.

d. Teens / publishers seek new values by testing new values by testing old values with new ideas.

e. The teenager/puber begins to realize that the freedom and freedom he seeks requires knowledge and skills.

f. Teenagers / pubers often act as slaves to adjust their behavior with group excitement due to the feeling of being not guaranteed of recognition from the group.

g. Teenagers / pubers do aberrant acts to simply be accepted within the group.

To facilitate parents in educating teenagers / pubers need to pay attention as follows[3]:

a) A deep understanding of youth, problems and needs.

b) It should be endeavored for adolescents to understand themselves, their families, schools, and society.

c) There should be found a way or method in educating adolescents who are always adjusted to the changes that occur in him and changes that occur outside himself.

d) It should help teenagers develop a value system that will give them the ability to form a realistic "I" concept that can help them make choices about their personal and social activities.

e) Teenagers are involved in deciding what to do, not just doing what the parents have decided.

As a reference material or comparison is discussed about some educational measures imposed on teenagers / pubes as follows:

1) Conduct a dialogue with the child so that we can recognize the child appropriately, which is the basic capital to educate them appropriately.

2) 2) We strive to make our teenager not feel alienated from the family.

3) 3) Give our teenagers a chance to freely build themselves, their responsibilities, and their future with what they have chosen.

4) 4) Implement democratic systems and togetherness in discussing and taking decisions.

5) 5) Radiating authority as a parent by constantly becoming a boost and pride for our teenage children.

6) 6) Be alert, not suspect changes that occur to our teenage individual from day to day, time to time.

7) 7) We must be able to refrain from always wanting to know the affairs of children, so it does not create the impression for our children feel insecure to be near parents.

8) 8) Welcome hospitality to every guest of our children who come to the house together or not with our children. 
9) 9) Especially concerning the issue of wanting to be loved and loved by teenagers, we must understand that feeling and not compare it with our past stories about our relationship with our spouse.

10) 10) We must avoid making something contradictory in the family such as decision making, determination of parental policies, obligations of children and others that cause children to be confused.

11) Giving a congratulations or congratulations on the achievements of our children, even small speeches.

12) Regarding the issue of formal education is to provide an explanation of the purpose of schooling and explain to adolescents that the failure in formal education in school is not the end of everything.

13) In the case of parents feel and indeed the fact is no longer able to finance the education of children should talk openly to children without having to feel prestige or fear.

14) Introduce to teenagers the principles of work, so that later when he has started to work will behave and act right.

15) We must teach good morals and educate our youth to be human beings who have the means for all.

\section{Educate Children to be Noble in Moral (Berakhlak}

Mulia)

Akhlak are a state inherent in the human psyche, from which it is born easily deeds, without going through thought processes, considerations and research. According to the mind and the syara "(Islamic law) is called the good alkhlah. His name morality that spontaneous action, free of engineering and certain interests[9].Some Akhlak (noble character) requirements can be fulfilled as follows: (a) The act was done repeatedly. (b) If an act is done only once, then it can not be called morals. (c). The mutation arose easily without being thought through or examined first, so it really is a habit.

State of The Art for Educating Akhlakto Children : (1) Akhlakdeeds to God; (2) Akhlakdeeds to parents; (3) Akhlakto the teacher; (4) Akhlakdeeds towards you; (5) Akhlak deeds to friends; and (6) Akhlakdeeds to neighbors

Akhlak (noble) character of speech is like using polite words, speaking in a pleasant voice and keeping a speech. Noble deeds in the form of deeds, doing deeds in an orderly, orderly and polite manner. Akhlakcharacter in the form of attitude, akhlakcharacter in the form of clothing appearance. Dressed polite and neatly in accordance with the appropriate atmosphere, place, time with clothes in wear.

Akhlak character in the family, at work, work disciplined, productive, industrious and skilled. Glorious nobility in public places such as caring for things that can interfere with comfort, security, and safety in public places and do something that prevents it.

\section{CONCLUSIONS}

Education in the family is the main education and first obtained by the child, because the first time children know the various values and norms in life. The main education is education in the family oriented to moral education and the rules of life instilled by the family through care and compassion. In the family the child is taught to communicate and perform actions that do not violate the norms of life such as hospitality, honesty, trust and respect for others. Parents are very instrumental in bringing the child towards independence and maturity. There are several stages that are done in the family in the education of children according to age and developmental level. The following describes the child's education strategy in the family: (a) during pregnancy; (b) under-five; (c) of age of Kindergarten; (d) Primary school age; (e) Junior High School age and (f) High School age. The foundation in family education is moral education and character then explained also about moral education of children in the family.

Akhlak have spontaneous deeds, free of engineering and certain interests. Some moral requirements can be fulfilled as follows: (a) The act was done repeatedly. (b) If an act is done only once, then it can not be called morals. (c). The mutation arose easily without being thought through or examined first, so it really is a habit. Some morals demanded on a child, namely morals to God, parents, relatives, friends, neighbors, nature and so on.

\section{References}

[1] D. K. Albertus, Pendidikan Karakter: Strategi Mendidik Anak di Zaman Global. Jakarta: PT Grasindo, 2010.

[2] A. Hufad, "Peran Keluarga Inti dalam Pendidikan Anak," J. Pendidik. Luar Sekol., vol. I, no. 1, 2000.

[3] S. Lestari, Psikologi Keluarga: Penanaman Nilai dan Penanganan Konflik dalam Keluarga. Jakarta: Kencana Pranada Media Group, 2012.

[4] E. B. Surbakti, Parenting Anak-anak. Jakarta: Elex Media Komputindo, 2012.

[5] Y. N. Pujiono, Konsep Dasar Pendidikan Anak Usia Dini. Jakarta: PT Indeks, 2009.

[6] S. Patmonodewo, Pendidikan Anak Prasekolah. Jakarta: Rineka Cipta, 2003.

[7] D. Kesuma, C. Triatna, and J. Permana, Pendidikan Karakter Kajian Teori dan Praktik di Sekolah. Bandung: PT Remaja Rosdakarya, 2011.

[8] R. Megawangi, Pendidikan Karakter: Solusi yang Tepat untuk Membangun Bangsa. Jakarta: Indonesia Heritage Foundation, 2004.

[9] R. N. Ningsih, "Hubungan Intensitas Pengasuhan Orang Tua dengan Perkembangan Sosial-Emosional Anak Usia Dini," $J$ Pendidik. Nonform., vol. 6, no. 55-62, 2012. 